\title{
Rancangan Sistem Pembangkit Listrik Tenaga Surya On-Grid Kapasitas 20 kWp untuk Residensial
}

\author{
Daryal Fuaddin, Aceng Daud, ST., M.Eng. \\ Program Studi Teknologi Pembangkit Tenaga Listrik, \\ Jurusan Teknik Konversi Energi, Politeknik Negeri Bandung, Indonesia \\ email : daryal.fuaddin.tpt114@polban.ac.id; aceng.daud@ polban.ac.id
}

\begin{abstract}
Abstrak
Pada rancangan proyek ini akan dirancang PLTS berkapasitas $20 \mathrm{kWp}$ pda atap rumah yang mampu membangkitkan $20 \mathrm{~kW}$ pada jam-jam efektif mataharinya. Rancangan PLTS ini akan terdiri dari panel-panel surya inverter dan beberapa alat pengaman serta $\mathrm{kWh}$ meter, namun pada studi ini akan membahas panel surya dan inverternya saja. Kemudian akan membahas analisis pengaruh pergerakkan matahari dan orientasi pemasangan, analisis produksi dan rugi-rugi pembangkitan, analisis manfaat penghematan dan analisis ekonominya. Rancangan disimulasikan dengan aplikasi PVsyst dengan input 56 modul ber-plot 4 string dan 2 array. Analisis perspektif plotting untuk mengetahui pengaruh pergerakkan matahari dan orientasi plotting terhadap besar produksi energi listrik juga dilakukan. Dari hasil simulasi, didapatkan besar pengurangan energi iradiasi matahari pada kolektor sebesar 15,4\%. Kemudian Produksi energi listrik satu tahun simulasi dapat mencapai $23.753 \mathrm{kWh}$ sesuai dengan plotting panel serta pengaruh kemiringan panel dan pergerakkan mataharinya. Rugi-ruginya mencapai angka $17 \%$ sehingga rasio pembangkitannya 0.822 yang cukup baik untuk sebuah PLTS karena pada umumnya hanya 0,75 saja. Rugi kolektornya (Array losses) mencapai 0,62 kWh/kWp per harinya sedangkan rugi sistemnya mencapai 0,1 kWh/kWp per harinya. Untuk rincian rugi-ruginya juga dapat di rangkum dalam loss diagram. Payback periodnya pada tahun ke 10 yang dimana waktu asuransi tiap panel suryanya hanya 10 tahun. Lalu dilihat dari nilai NPV pada tahun ke25 proyek (umur pembangkit), nilainya sebesar Rp 303.272.654,4. Manfaat penghematan juga sangat baik karena mencapai angka rasio sekitar 44\%-50\%.
\end{abstract}

Kata Kunci: PVsyst, Loss diagram, NPV, Sun Path Diagram, PLTS.

\section{PENDAHULUAN}

Energi listrik sudah menjadi kebutuhan sehari-hari bagi rakyat dunia. Perkembangan budaya global juga sangat memicu berkembangnya kebutuhan listrik. Begitu juga Indonesia yang merupakan salah satu negara berkembang, melakukan banyak pembangunan dalam lingkup pemukiman, lahan kerja dan sebagainya sehingga kebutuhan energi listrik meningkat tajam. Perkembangan fasilitas pembangkitan listrik di Indonesia sudah marak seiring dengan adanya rencana daya listrik 35.000 MW pada era kepemimpinan presiden Joko Widodo.

Pembangkit listrik tenaga bersih dan terbarukan menjadi hal yang sangat menarik untuk dikembangkan karena tidak merusak lingkungan dan memiliki sumber tak terbatas. PLTS memiliki kemampuan untuk mengkonversi energi yang dihasilkan oleh radiasi matahari namun memiliki beberapa kekurangan. Pengoperasian PLTS hanya dapat dilakukan beberapa jam saja yaitu ketika adanya sinar matahari (pagi hari sampai sore hari). Sudah banyak pula pengembangan PLTS dengan menggunakan metode energystorage yang berupa baterai untuk menyimpan kelebihan energi yang dibangkitkan agar dapat digunakan pada malam hari.

Namun penggunaan energy storage menambah biaya pemasangan dan biaya pemeliharaan. Oleh karena itu dalam karya tulis ini akan dibahas perancangan sistem ongrid yang terpasangi sistem net-metering PLN. Dengan sistem ini kelebihan pembangkitan energi listrik tidak akan disimpan pada baterai melainkan akan dijual pada PLN. Dengan metode ini tempattempat yang dipasangi panel surya akan berperan juga dalam pembangkitan listrik nasional

\section{METODOLOGI PENELITIAN}

Rancangan PLTS on-grid kapasitas $20 \mathrm{kWp}$ bertahap seperti Gambar.1.
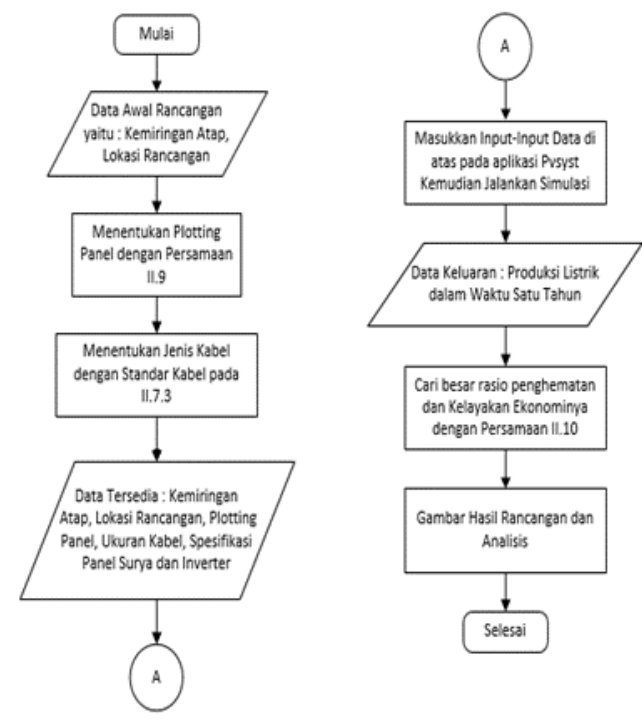

Gambar.1 Diagram alir rancangan PLTS

\section{II.1 Orientasi Panel Surya dan Data Matahari}

Data awal berupa kemiringan atap $45^{\circ}$ menghadap barat dan timur karena rumah menghadap ke utara (Gambar 2). Selain itu lokasi rancangan berada di Jakarta (Gambar 3) 


\begin{tabular}{|c|c|c|c|}
\hline Jurnal Energi & Volume 10 Nomor 1 & November 2020 & ISSN: 2089-2527 \\
\hline
\end{tabular}
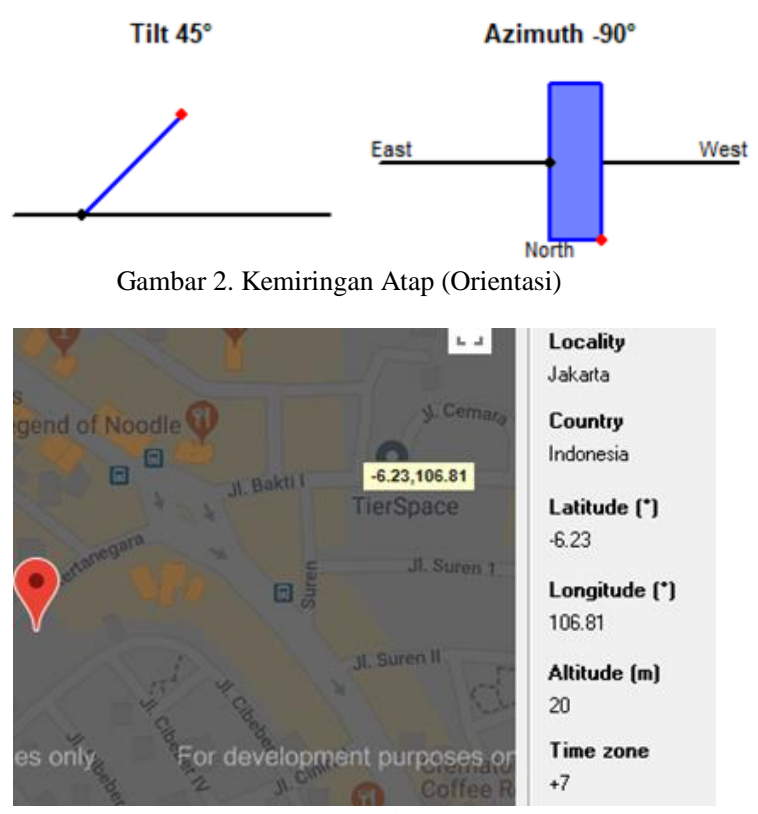

Gambar 3. Lokasi Rancangan

\begin{tabular}{|c|c|c|c|c|}
\hline \multirow[t]{2}{*}{ Data source } & \multicolumn{4}{|c|}{ Meteonorm 7.2(2010-2014). Sat=100\% } \\
\hline & $\begin{array}{c}\text { Global Irrad. } \\
\qquad W / \mathrm{m}^{2}\end{array}$ & $\begin{array}{c}\text { Diffuse } \\
\mathrm{W} / \mathrm{m}^{2}\end{array}$ & $\begin{array}{c}\text { Temper. } \\
{ }^{\circ} \mathrm{C}\end{array}$ & $\begin{array}{l}\text { Wind Vel. } \\
\mathrm{m} / \mathrm{s}\end{array}$ \\
\hline January & 146.9 & 86.3 & 25.8 & 1.61 \\
\hline February & 166.5 & 108.2 & 25.5 & 1.60 \\
\hline March & 191.4 & 90.5 & 26.1 & 1.60 \\
\hline April & 204.6 & 103.1 & 26.1 & 1.30 \\
\hline May & 200.8 & 96.1 & 26.5 & 1.09 \\
\hline June & 196.3 & 89.0 & 25.8 & 1.08 \\
\hline July & 197.8 & 93.5 & 25.9 & 1.09 \\
\hline August & 226.2 & 103.8 & 26.0 & 1.20 \\
\hline September & 224.4 & 113.8 & 26.1 & 1.20 \\
\hline October & 211.2 & 119.8 & 26.7 & 1.30 \\
\hline November & 240.3 & 116.1 & 26.0 & 1.19 \\
\hline December & 177.3 & 105.6 & 25.9 & 1.50 \\
\hline Year & 198.7 & 102.1 & 26.0 & 1.3 \\
\hline
\end{tabular}

Gambar 4. Data Matahari

Dapat dilihat dari Gambar 4 yang merupakan antarmuka aplikasi PVsyst yang menampilkan data matahari setelah membaca inputan lokasi.

\section{II.2 Menentukan Plotting PLTS}

Plotting panel dapat ditentukan dengan rumus-rumus berikut

Jumlah modul $P V=\frac{\text { Kapasitas rancangan } P L T S}{\text { Kapasitas panel surya }} \ldots$

$V_{m p p}$ total $=$ Jumlah modul $P V x V_{\text {mpp }} /$ Modul $\ldots \ldots .$.

$V_{m p p}=V_{m p p}$ total jumlahstring

\section{Dengan syarat-syarat}

$\mathrm{V}_{\text {startup }}<\mathrm{V}_{\mathrm{mpp}}<\mathrm{V}_{\mathrm{mppt}}$

$\mathrm{I}_{\mathrm{mpp}}<\mathrm{I}_{\mathrm{mppt}}$

$V_{m p p}=$ Tegangan dalam 1 seri (string) panel surya

$I_{m p p}=$ Arus dalam 1 paralel (array) panel surya

$V_{m p p t}=$ Tegangan nominal inverter

$I_{m p p t}=$ Arus nominal inverter
Panel Surya yang digunakan adalahREC 350 TwinPeak 2 S 72 yang menghasilkan $350 \mathrm{~W}$ pada kondisi STC (Standard Test Conditions), di mana tegangan nominalnya adalah $38,9 \mathrm{~V}$ dan arus nominalnya $9 \mathrm{~A}$.

Inverter yang digunakan adalah ABB TRIO-20.0-TL-OUTD yang dimana tegangan start-upnya adalah $420 \mathrm{~V}$ lalu tegangan nominal inverternya adalah $620 \mathrm{~V}$ dan arus nominalnya adalah $25 \mathrm{~A}$ masing-masing input MPPT-nya (maksimal bila parallel atau kedua input MPPT digunakan $50 \mathrm{~A}$ ).

Ukuran kabel dapat ditentukan dengan standar AKLI pada Tabel II.1 berikut.

\begin{tabular}{|c|c|c|c|c|c|c|c|c|c|c|}
\hline \multicolumn{11}{|c|}{ Der 11. } \\
\hline \multicolumn{3}{|c|}{ BESARAN DAYA YG TERSEDLA } & \multirow{2}{*}{$\frac{\text { Watt }}{\text { QPf }=0.8}$} & \multirow{2}{*}{ Gol } & \multicolumn{2}{|c|}{ MCB/UCCB } & \multirow{2}{*}{$\mathrm{v}$} & \multirow{2}{*}{$\begin{array}{c}\text { Type Kabel } \\
\text { Toefoer }\end{array}$} & \multirow{2}{*}{\multicolumn{2}{|c|}{$\begin{array}{c}\text { Besar Kabel by } \\
\text { AKu }\end{array}$}} \\
\hline VA & rounded (Na) & KVA & & & A & Fase & & & & \\
\hline 450 & & 0,45 & 360 & Th & 2 & 10 & $220 \mathrm{~V}$ & mYrimm & $3 \times 25$ & $5 \mathrm{~mm}^{2}$ \\
\hline 900 & & 0,9 & 720 & Th & 4 & 10 & $220 \mathrm{~V}$ & m & $3 \times 25$ & $5 \mathrm{~mm}^{3}$ \\
\hline 1300 & & 1.3 & 1040 & TR & 6 & 10 & $220 \mathrm{~V}$ & m & $3 \times 4$ & $\mathrm{~mm}^{2}$ \\
\hline 2200 & & 2.2 & 1.760 & TR & 10 & 10 & $220 \mathrm{~V}$ & мучимм & $3 \times 4$ & $\mathrm{~mm}^{4}$ \\
\hline 3500 & & 3.5 & 2800 & TR & 16 & 10 & $220 \mathrm{~V}$ & mer/ams & $3 \times 4$ & $\mathrm{~mm}^{2}$ \\
\hline 4400 & & 4.4 & 3520 & TR & 20 & 10 & $220 \mathrm{~V}$ & merims & $3 \times 4$ & $\mathrm{~mm}^{2}$ \\
\hline 3500 & & s.s & 4.450 & Th & 25 & 10 & $220 \mathrm{~V}$ & norismu & $3 \times 4$ & $\mathrm{~mm}^{2}$ \\
\hline 7700 & & 7,7 & 6.160 & TR & 35 & 10 & $220 \mathrm{~V}$ & rinm & $3 \times 6$ & $\mathrm{~mm}^{2}$ \\
\hline 11000 & & $n$ & 8800 & TR & 50 & 10 & $220 \mathrm{~V}$ & n/mon & $3 \times 6$ & $\mathrm{~mm}^{2}$ \\
\hline 13900 & & 13,9 & 11.120 & Th & 63 & 10 & $220 \mathrm{~V}$ & 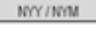 & $3 \times 10$ & $\mathrm{~mm}^{3}$ \\
\hline 3949 & 3900 & 3,9 & 3159 & TR & 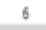 & 30 & $380 \mathrm{~V}$ & NYINFGBY & $4 \times 4$ & $\mathrm{~mm}^{2}$ \\
\hline 6582 & 6600 & 6.6 & 5265 & $T R$ & 10 & 30 & $380 \mathrm{~V}$ & NYYIMFGEY & $4 \times 4$ & $\mathrm{~mm}^{2}$ \\
\hline 20531 & 10.600 & 10,6 & 8.425 & $T R$ & 16 & 30 & $380 \mathrm{~V}$ & NYYINFGEY & $4 \times 6$ & $\mathrm{~mm}^{2}$ \\
\hline 13.164 & 13200 & 13.2 & 10.531 & Th & 20 & 30 & $380 \mathrm{~V}$ & NYYIMFGEY & $4 \times \quad 10$ & $\mathrm{~mm}^{2}$ \\
\hline 16.554 & 16590 & 165 & 13.154 & $T R$ & 25 & 30 & $380 \mathrm{~V}$ & WYIMFGEY & $4 \times 10$ & $\mathrm{~mm}^{2}$ \\
\hline 23036 & 23000 & 23 & 18.429 & $\mathrm{TR}$ & 35 & 30 & $300 \mathrm{~V}$ & INIIMFGEY & $4 \times \quad 16$ & $\mathrm{~mm}^{2}$ \\
\hline 32909 & 33000 & 33 & 26327 & $T^{T}$ & so & 30 & $380 \mathrm{~V}$ & NYYINFGEY & $4 \times \quad 16$ & $\mathrm{~mm}^{2}$ \\
\hline 41.465 & 41.500 & 41,5 & 33.172 & TR & 63 & 30 & $380 \mathrm{~V}$ & NWYINFFEY & $4 \times 25$ & $\mathrm{~mm}^{2}$ \\
\hline 52654 & 53000 & 53 & 42123 & TR & 80 & 30 & $300 \mathrm{~V}$ & NYYINFGEY & $4 \times 35$ & $\mathrm{~mm}^{2}$ \\
\hline 65818 & 65000 & 66 & 52654 & $\mathrm{TR}$ & 100 & 30 & $380 \mathrm{~V}$ & NWYINFGBY & $4 \times 50$ & $\mathrm{~mm}^{2}$ \\
\hline 82272 & 82550 & 825 & $65: 818$ & $\mathrm{Th}$ & 125 & 30 & $380 \mathrm{~V}$ & NYYINFGEY & $4 \times 50$ & $m m^{2}$ \\
\hline 105309 & 105000 & 105 & 84247 & Th & 160 & 30 & $380 \mathrm{~V}$ & NOTINMFGEY & $4 \times 70$ & $\mathrm{~mm}^{2}$ \\
\hline 131636 & 131000 & 131 & 105.309 & $\mathrm{TR}$ & 200 & 30 & $380 \mathrm{~V}$ & NYYIMFGEY & $4 \times 95$ & $\mathrm{~mm}^{\mathrm{t}}$ \\
\hline
\end{tabular}

\section{II.3 Simulasi Rancangan dengan aplikasi PVsyst}

Parameter-parameter input yang telah didapat sebelumnya berupa kemiringan atap, plotting panel surya, lokasi rancangan dan ukuran kabel dapat dimasukkan ke dalam aplikasi PVsyst untuk disimulasikan. Gambar 5 adalah antarmuka PVsyst untuk rancangan on-grid.

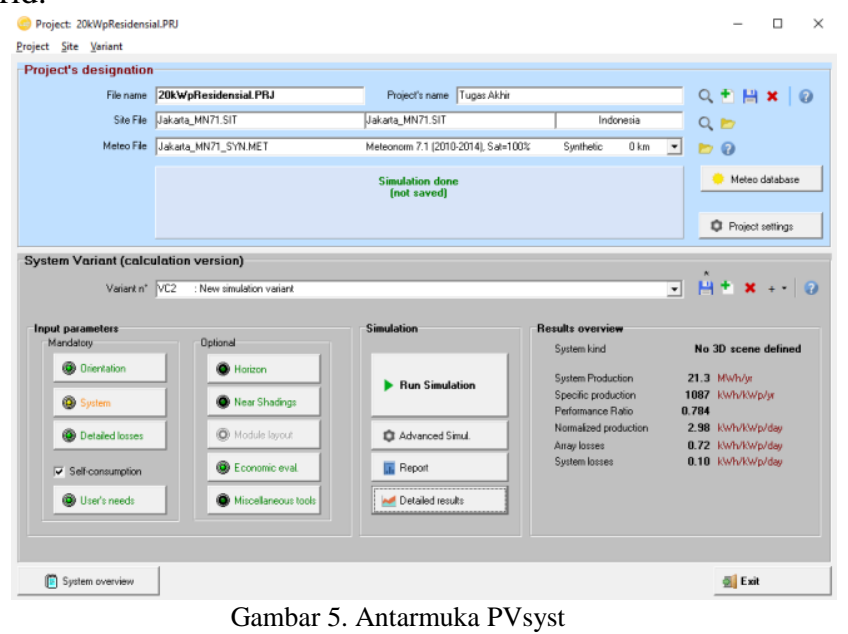

Gambar 5 di atas adalah antarmuka PVsyst. Terlihat pada gambar ada opsi Meteo database, Orientation, System dan Detailed Losses. Masukkan input lokasi rancangan pada opsi Meteo database, input kemiringan atap pada opsi Orientation, input plotting panel surya, tipe PV dan tipe inverter pada opsi System dan masukkan input ukuran kabel pada opsi Detailed losses. 


\section{II.4 Evaluasi Ekonomi Rancangan}

Setelah parameter-parameter input disimulasikan oleh PVsyst yang menghasilkan data produksi, selanjutnya dibuat evaluasi kelayakan ekonominya dengan rumus-rumus berikut:

$$
\text { Net Cash Flow }=\sum_{y=1}^{y=n} \frac{\left(S_{y} \times P_{P y}+G_{t o t y} \times P_{e c} y+O_{y} \times P_{g b y}-k \times I_{0}-F_{f e e}\right)}{(1+r)^{y-1}}
$$

Cash flow dicari untuk membuat kurva NPV selama umur pembangkitan yaitu 25 tahun.

Berikut rumus NPV-nya:

$$
N P V=\text { Net Cash Flow }-I_{o}-\frac{I_{R}}{(1+r)^{15}}
$$

\section{HASIL DAN PEMBAHASAN}

Gambar 6 di bawah ini merupakan hasil dari simulasi berupa pengaruh pergerakkan matahari yang di mana gambar pertama adalah kurva waktu orientasi 1 panel surya yang dipasangi menghadap ke timur dengan kemiringan orientasi $45^{\circ}$, sedangkan gambar kedua adalah orientasi 2 panel surya yang menghadap ke barat dengan kemiringan orientasi $45^{\circ}$
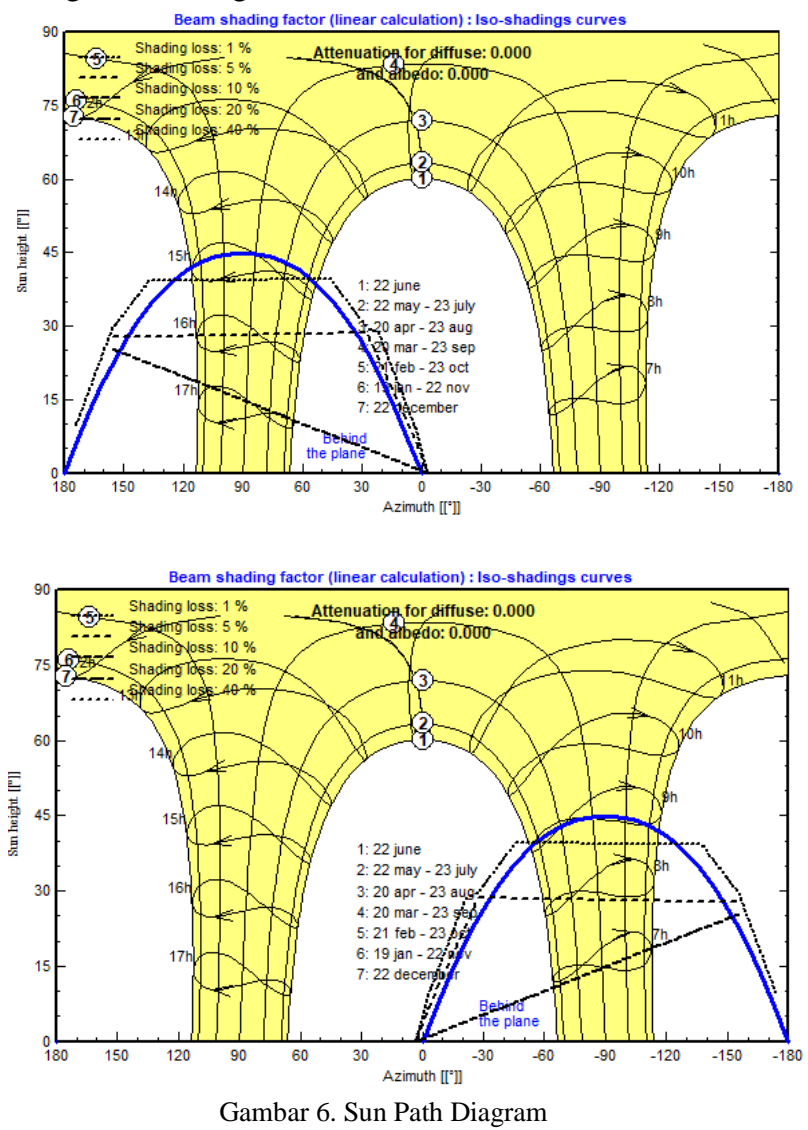

Pada Gambar 6 dapat dilihat sun path diagram yang merupakan kurva waktu ketika masing-masing orientasi tertutupi oleh matahari. Jadi dapat dilihat bahwa orientasi 1 panel surya membelakangi matahari setelah jam 3 sore, kemudian orientasi 2 panel surya membelakangi matahari sebelum jam 9 pagi.

Kemudian untuk hasil simulasi berupa besar rugi-rugi ada di bawah ini

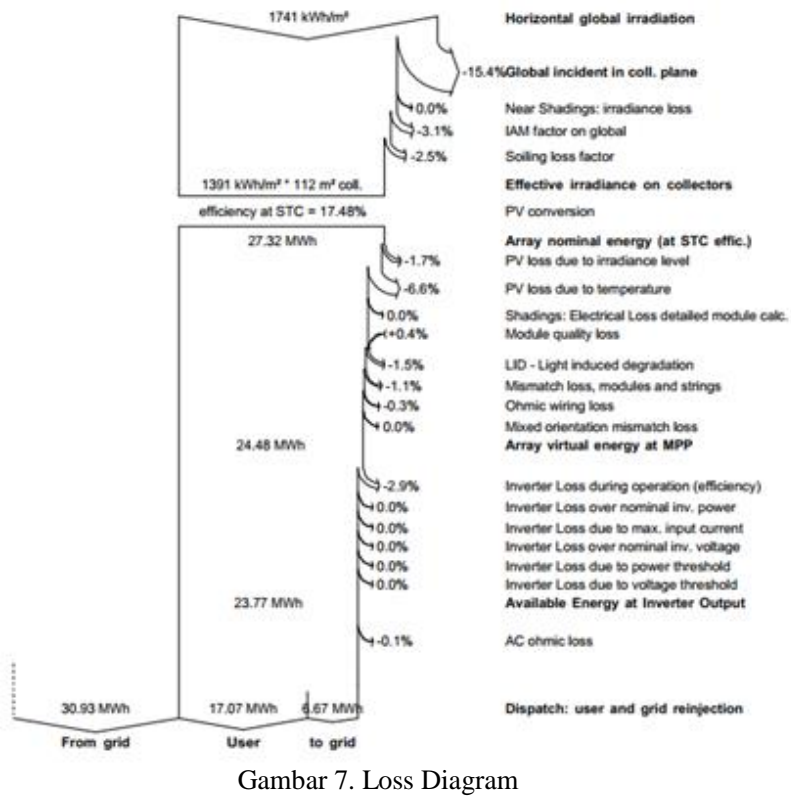

Gambar 7. adalah loss diagram yang merupakan diagram yang menjelaskan rugi-rugi dari iradiasi matahari yang datang sampai rugi-rugi sistem di dalam PLTS. Pada awal gambar diberikan data total energi yang dapat diterima oleh sel PV per meter perseginya bila posisinya horizontal pada permukaan bumi sebesar 1741 $\mathrm{kWh} / \mathrm{m}^{2}$ (Horizontal Global Irradiation).

Pengurangan energi yang diterima sebesar $15,4 \%$, yang di mana hal ini disebabkan oleh faktor peletakkan panel surya dan faktor perubahan posisi matahari tiap harinya. Faktor peletakkan sel ini dijelaskan pada analisis pergerakkan matahari sebelumnya.

IAM losses (rugi refleksi iradiasi matahari pada panel surya) dari sistem sebesar $3,1 \%$, hal ini disebabkan oleh pantulan pada bahan gelas yang menjadi pelindung sel-sel PV didalamnya. Kemudian rugi kotor (soiling factor) sebesar 2,5\% adalah input yang dimasukkan berdasarkan besar umum yang diberikan oleh aplikasi PVsyst. Lalu faktor bayangan (near shading) sebesar $0 \%$ karena tidak ada pepohonan yang lebih tinggi dari atap rumah lokasi proyek PLTS $20 \mathrm{kWp}$ residensial ini. Sehingga besar iradiasi yang efektif diterima kolektor (sel surya) adalah sebesar $1391 \mathrm{kWh} / \mathrm{m} 2$.

PV irradiance level sebesar 1,7\%, di mana losses ini dipengaruhi oleh besar iradiasi. Efisiensi pembangkitan akan berkurang bila iradiasi matahari yang diterima juga kecil. Kemudian faktor akibat temperatur sebesar $6,6 \%$, di mana bila suhu naik akan menyebabkan kenaikan arus dan turunnya tegangan yang berarti akan terjadi panas berlebih atau dapat disebut daya yang hilang. Kemudian parameter seperti module quality loss, light induced degradation, ohmic losses, dan inverter loss adalah parameter berdasarkan hasil simulasi dari spesifikasi yang digunakan dalam proyek.

Dari losses diagram (Gambar 7) dapat ditunjukkan bahwa energi yang dapat dibangkitkan sistem sebesar 27,32 MWh mengalami penurunan akibat rugi-rugi dalam sistem hingga 23,77 MWh. Kemudian pada bagian bawah dijelaskan bahwa penggunaan pertahun rumah yang mencapai 48 MWh dapat membuat penggunaan listrik dari grid sekitar 30,93 MWh karena 17,07 MWhnya didapat dari hasil pembangkitan, dan daya hasil pembangkitan berlebih ketika jam efektif mataharinya dapat dijual ke grid sebesar 6,67 MWh.

Gambar 8 merupakan perbandingan iradiasi yang diterima kolektor (panel surya) dan energi yang diproduksi setiap harinya dalam 1 tahun simulasi. 


\begin{tabular}{|l|l|l|l|}
\hline Jurnal Energi & Volume 10 Nomor 1 & November 2020 & ISSN: 2089-2527 \\
\hline
\end{tabular}

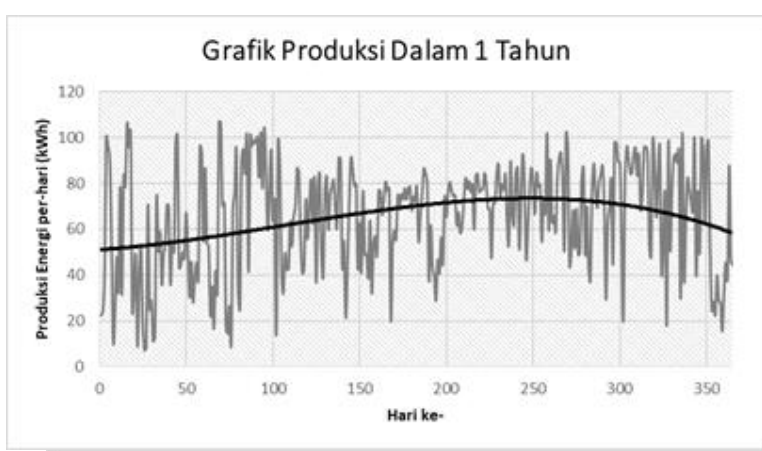

Enegi yang Diterima Panel Surya per $\mathrm{m}^{2}$ Tiap Hari

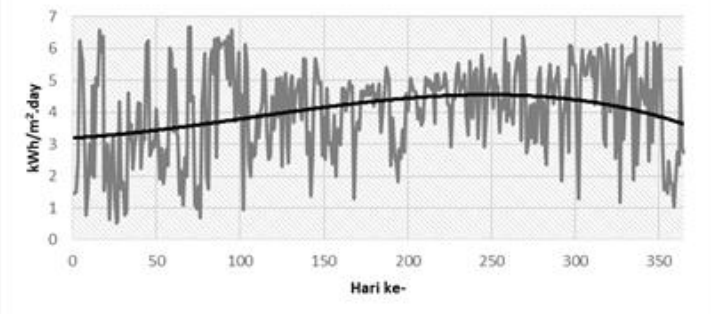

Gambar 8. Perbandingan Iradiasi Matahari pada Kolektor dengan Produksi Listrik Harian

Dari Gambar 8 di atas, dapat dilihat bahwa besar produksi listrik berbanding lurus dengan besar energi iradiasi matahari yang diterima kolektor atau panel surya (Global Incident on Collector Plane).

Gambar 9. di bawah ini adalah grafik penggunaan listrik rumah dalam 1 hari simulasi.

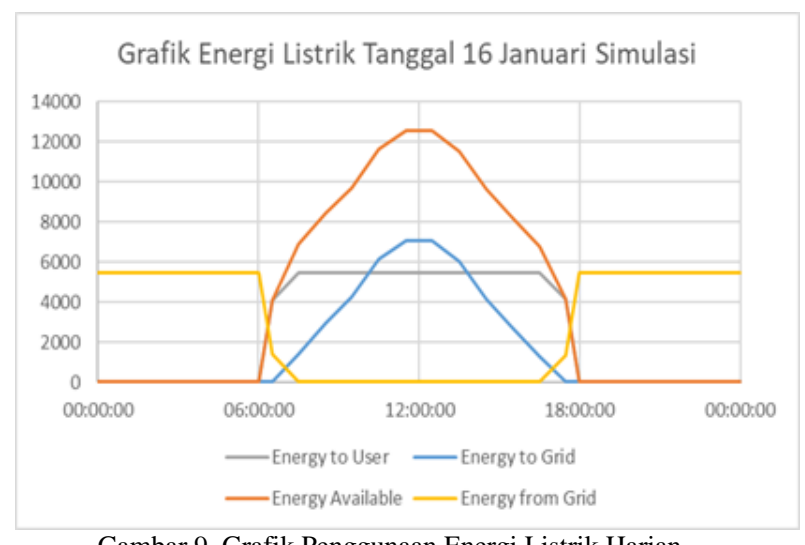

Gambar 9. Grafik Penggunaan Energi Listrik Harian

Dapat dilihat dari mulainya hari sampai jam 6 pagi listrik digunakan adalah listrik dari grid karena belum adanya produksi listrik dari panel surya. Kemudian mulai dari jam 6 pagi listrik dari grid mulai menurun karena konsumen mulai menerima listrik dari panel surya. Setelah panel surya sudah memenuhi kebutuhan konsumen, pln tidak lagi menyuplai listrik ke konsumen melainkan panel surya akan menyuplai listrik ke pln bila terjadi produksi berlebih. Hal ini, bila dilihat pada grafik, terjadi sekitar mulai jam 7. Lalu mulai dari jam 5 sore PLN kembali menyuplai listrik ke konsumen karena panel surya mulai tak bisa memenuhi kebutuhan konsumen. Setelah jam 6 sore, PLN kembali dengan penuh menyuplai energi listrik kepada konsumen karena matahari sudah terbenam.

Grafik di atas hanyalah sebuah contoh ketika hari sedang cerah sehingga tidak ada gangguan pada produksi listrik ketika siang hari. Dari PVsyst ada contoh di mana produksi listrik terganggu pada siang hari sehingga PLN tetap menyuplai listrik pada konsumen. Hal ini terjadi karena adanya hujan atau awan mendung yang menghalangi iradiasi matahari yang jatuh ke panel surya.

Gambar 10 adalah rangkuman peforma PLTS on-grid selama 1 tahun simulasi.

\begin{tabular}{|c|c|}
\hline \multicolumn{2}{|l|}{ Results overview } \\
\hline System kind & Sheds on a building \\
\hline System Production & $23.8 \mathrm{MWh} / \mathrm{yr}$ \\
\hline Specific production & $1212 \mathrm{kWh} / \mathrm{kW} / \mathrm{p} / \mathrm{yr}$ \\
\hline Performance Ratio & 0.822 \\
\hline Normalized production & $3.32 \mathrm{kWh} / \mathrm{kW} / \mathrm{p} /$ day \\
\hline Array losses & $0.62 \mathrm{kWh} / \mathrm{kW} / \mathrm{p} /$ day \\
\hline System losses & $0.10 \mathrm{kWh} / \mathrm{kW} / \mathrm{p} /$ day \\
\hline
\end{tabular}

Bila dilihat dari gambar di atas rasio peforma pembangkit sebesar 0,822 sudah cukup baik bila pada umumnya hanya 0,75 saja. Rugi kolektornya (Array losses) mencapai $0,62 \mathrm{kWh} / \mathrm{kWp}$ per harinya sedangkan rugi sistemnya mencapai $0,1 \mathrm{kWh} / \mathrm{kWp}$ tiap harinya. Rugi-rugi ini dijelaskan pada analisis loss diagram sebelumnya.

Tabel 2 di bawah ini merupakan rasio penghematan pembangkit selama umur pembangkit.

Tabel 2. Manfaat Penghematan yang diterima user

\begin{tabular}{|c|c|c|c|}
\hline Tahun & Konsumsi Energi & Produksi Energi & Penghematan \\
\hline ke- & kWh & kWh & $\%$ \\
\hline 1 & 48000 & 23753 & $49,49 \%$ \\
\hline 2 & 48000 & 23634,235 & $49,24 \%$ \\
\hline 3 & 48000 & 23516,06383 & $48,99 \%$ \\
\hline 4 & 48000 & 23398,48351 & $48,75 \%$ \\
\hline 5 & 48000 & 23281,49109 & $48,50 \%$ \\
\hline 6 & 48000 & 23165,08363 & $48,26 \%$ \\
\hline 7 & 48000 & 23049,25821 & $48,02 \%$ \\
\hline 8 & 48000 & 22934,01192 & $47,78 \%$ \\
\hline 9 & 48000 & 22819,34186 & $47,54 \%$ \\
\hline 10 & 48000 & 22705,24515 & $47,30 \%$ \\
\hline 11 & 48000 & 22591,71893 & $47,07 \%$ \\
\hline 12 & 48000 & 22478,76033 & $46,83 \%$ \\
\hline 13 & 48000 & 22366,36653 & $46,60 \%$ \\
\hline 14 & 48000 & 22254,5347 & $46,36 \%$ \\
\hline 15 & 48000 & 22143,26203 & $46,13 \%$ \\
\hline 16 & 48000 & 22032,54572 & $45,90 \%$ \\
\hline 17 & 48000 & 21922,38299 & $45,67 \%$ \\
\hline 18 & 48000 & 21812,77107 & $45,44 \%$ \\
\hline 19 & 48000 & 21703,70722 & $45,22 \%$ \\
\hline 20 & 48000 & 21595,18868 & $44,99 \%$ \\
\hline 21 & 48000 & 21487,21274 & $44,77 \%$ \\
\hline 22 & 48000 & 21379,77667 & $44,54 \%$ \\
\hline 23 & 48000 & 21272,87779 & $44,32 \%$ \\
\hline 24 & 48000 & 21166,5134 & $44,10 \%$ \\
\hline 25 & 48000 & 21060,68083 & $43,88 \%$ \\
\hline
\end{tabular}

Dapat dilihat rasio penghematan selama 25 tahun umur pembangkit bahwa angka rasio sekitar dari 44\%-50\% ini berarti PLTS sangat bermanfaat bagi pemilik rumah karena mampu memotong tagihan listriknya selama bertahun-tahun dengan jumlah yang sangat besar. Oleh karena itu proyek ini sangat bermanfaat bagi pemilik rumah.

Terakhir, dari Gambar 11 di bawah ini dapat dilihat kurva NPV selama 25 tahun umur pembangkit 


\begin{tabular}{|c|c|c|c|}
\hline Jurnal Energi & Volume 10 Nomor 1 & November 2020 & ISSN: 2089-2527 \\
\hline
\end{tabular}

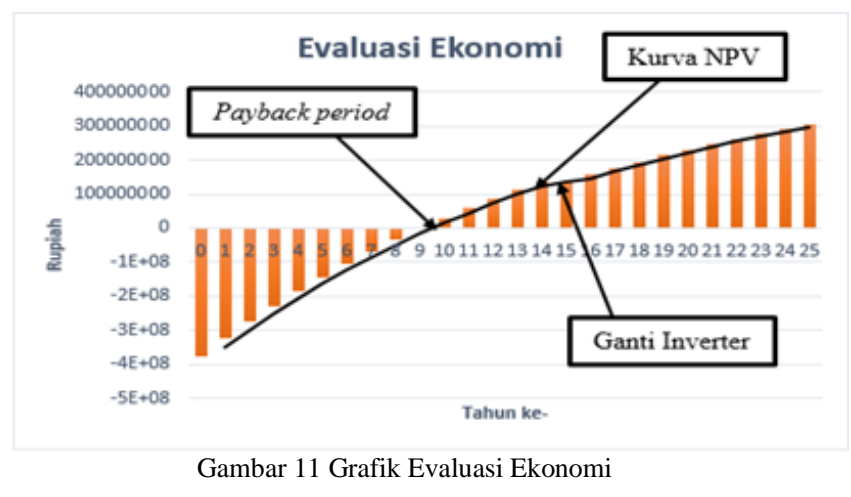

Dapat dilihat dari grafik di atas (Gambar 11) bahwa payback period terjadi pada tahun ke-10. Berdasarkan asumsi umur umum inverter tahun ke-15 maka pertumbuhan keuangan terhambat pada tahun 15 karena harus membeli inverter baru. Dapat simpulkan proyek ini cukup baik karena payback period di bawah 10 tahun yang di mana 10 tahun adalah batas asuransi dari setiap panel surya. Lalu proyek ini juga cukup baik karena pergantian inverter tidak membuat keuangan di bawah 0 rupiah saat tahun ke 15 . Nilai NPV yang didapat dari evaluasi ekonomi sudah positif ketika tahun ke-10 yaitu sebesar Rp 29.891.314,96. Nilai tersebut positif yang berarti proyek ini layak dilaksanakan.

\section{KESIMPULAN}

Pengaruh pergerakkan matahari serta kemiringan panel surya akibat konstruksi atap dengan sudut $45^{\circ}$ cukup besar mengurangi energi iradiasi matahari yang diterima panel surya (Global Incident on Collector Plane) mencapai 15,4\% (ditunjukkan pada diagram rugi-rugi).

Produksi energi listrik satu tahun simulasi dapat mencapai $23.753 \mathrm{kWh}$ sesuai dengan plotting panel serta pengaruh kemiringan panel dan pergerakkan mataharinya. Rugi-ruginya mencapai angka $17 \%$ sehingga rasio pembangkitannya 0.822 yang cukup baik untuk sebuah PLTS karena pada umumnya hanya 0,75 saja. Rugi kolektornya (Array losses) mencapai 0,62 $\mathrm{kWh} / \mathrm{kWp}$ per harinya sedangkan rugi sistemnya mencapai 0,1 $\mathrm{kWh} / \mathrm{kWp}$ per harinya. Untuk rincian rugi-ruginya juga dapat di rangkum dalam loss diagram. Loss diagram mencakup pengurangan energi iradiasi yang diterima kolektor (global incident on collector plane), rugi pada kolektor dan rugi sistem.

Faktor ekonomi dari proyek rancangan ini juga sudah baik bila dilihat dari payback periodnya pada tahun ke 10 yang dimana waktu asuransi tiap panel suryanya hanya 10 tahun. Kemudian ketika penggantian inverter pada tahun ke-15 net cash flow-nya tidak di bawah angka 0. Lalu dilihat dari nilai NPV pada tahun terjadipayback period yaitu pada tahun ke-10 proyek, nilainya sebesar Rp 29.891.314,96 yang di atas angka 0 yang berarti proyek ini menguntungkan dan layak dijalankan (feasible). Kemudian untuk manfaat penghematan juga sangatlah baik karena mencapai angka rasio sekitar 44\%-50\%. Pemilik rumah akan sangat diuntungkan dengan pemotongan tagihan listrik yang cukup besar.

\section{DAFTAR PUSTAKA}

[1] ABB. (2017). Catalog String Combine for Solar Photovoltaic Systems.

[2] ABB. (2017). Solar Inverter ABB String Inverers Trio-20.0/27.6-TLOUTD 20 to $27.6 \mathrm{~kW}$.

[3] Johansson, N., \& Karlsson, J. (2015). Economic Feasibility for Solar PV in Swedish Office Buildings. Goteborg: Chalmers University of Technology.

[4] Karsoho, E. (2018). Proposal PLTS Umara House - Bali 2.45 kWp. Lein Power.

[5] Klever, M. (2018). Design and simulation of a gridconnected PV system in South Africa: technical, commercial and economical aspects. Norwegian University of Life Sciences.

[6] Mayfield, R. (2010). Photovoltaic Design \& Installation for Dummies. Canada: Wiley Publishing, Inc.

[7] Mermoud, A., \& Wittmer, B. (2017). PVSYST 6. Satigny: PVSyst.

[8] REC. (t.thn.). REC Twinpeak $2 S 72$ Series. 